\title{
Pengaruh Profitabilitas, Kebijakan Dividen, dan Struktur Modal pada Nilai Perusahaan
}

\author{
Ni Kadek Puspita Yadnya Dewi ${ }^{1}$ \\ Fakultas Ekonomi dan Bisnis \\ Universitas Udayana, Indonesia. \\ Email: yadnyadewi@rocketmail.com
}

\author{
Ida Bagus Putra Astika² \\ Fakultas Ekonomi dan Bisnis \\ Universitas Udayana, Indonesia.
}

\begin{abstract}
ABSTRAK
Tujuan penelitian ini untuk mengetahui bukti empiris pengaruh profitabilitas, kebijakan dividen, dan struktur modal pada nilai perusahaan LQ45 yang terdaftar di Bursa Efek Indonesia periode 2014-2018. Sampel dipilih menggunakan teknik purposive sampling sehingga jumlah sampel yang diperoleh sebanyak 6 perusahaan dengan jumlah pengamatan dengan periode penelitian selama 5 tahun adalah sebanyak 30 amatan. Populasi penelitian sebanyak 68 perusahaan. Teknik analisis data yang digunakan adalah regresi linear berganda. Berdasarkan hasil analisis yang telah dilakukan diperoleh bahwa profitabilitas, kebijakan dividen, dan struktur modal secara signifikan berpengaruh positif pada nilai perusahaan.

Kata Kunci : Profitabilitas; Kebijakan Dividen; Struktur Modal; Nilai Perusahaan.

\section{The Effect of Profitability, Dividend Policy and Capital Structure on Company Value}

\section{ABSTRACT}

The purpose of this study is to know empirically the effect of profitability, dividend policy and capital structure on the value of LQ45 companies listed on the Indonesia Stock Exchange for the period 2014-2018. Samples were selected using purposive sampling technique to obtain a total sample of six companies, so the number of observations with a study period of 5 years was 30 observations. Total populations were sixtyeight companies. The data analyse technique used is multiple linear regression analysis. Based on the analysis that has been done shows that the probability, dividend policy and capital structure significant positive effect on value of the company.

Keywords: Profitability; Dividend Policy; Capital Structure; Company Value.

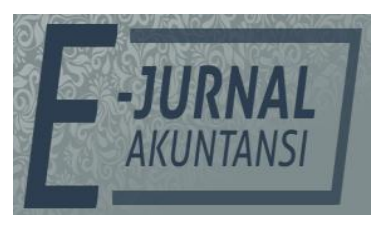

E-JA

e-Jurnal Akuntansi e-ISSN 2302-8556

Vol. 29 No. 2

Denpasar, November

2019

Hal. 804-817

Artikel masuk: 09 September 2019

Tanggal diterima: 05 November 2019 


\section{PENDAHULUAN}

Salah satu tujuan yang dimiliki perusahaan adalah untuk mempertahankan eksistensinya diantara ketatnya persaingan bisnis. Eksistensi perusahaan dapat dipertahankan dengan adanya peningkatan nilai perusahaan tiap periode yang akan memengaruhi kesejahteraan para investor (Apsari \& Setiawan, 2018). Nilai perusahaan dapat dilihat dari harga saham di Bursa Efek bagi perusahaan yang sudah go public. Perusahaan di Bursa Efek Indonesia di kelompokkan dalam beberapa bagian salah satunya adalah perusahaan LQ45. Perusahaan LQ45 merupakan nilai kapitalisasi pasar dari 45 saham yang paling likuid dan indeks LQ45 adalah 45 saham yang terpilih berdasarkan likuiditas perdagangan saham disesuaikan setiap enam bulan yaitu bulan Februari sampai Juli dan bulan Agustus sampai Januari.

Optimalisasi nilai perusahaan yang merupakan tujuan perusahaan dapat. dicapai melalui pelaksanaan fungsi manajemen keuangan, dimana suatu keputusan keuangan yang diambil akan mempengaruhi keputusan keuangan lainnya dan berdampak pada nilai perusahaan (Fama, 1998). Nilai perusahaan diukur menggunakan rasio Price to Book Value (PBV) yang menggambarkan seberapa besar pasar menghargai nilai buku perusahaan, sehingga perubahan harga saham ikut mempengaruhi perubahan nilai Price to Book Value (PBV). Tabel 1. merupakan nilai perusahaan indeks saham LQ45 di BEI yang diukur menggunakan Price to Book Value (PBV) periode tahun 2014-2018.

Tabel 1. Nilai Perusahaan Indeks Saham LQ45 di BEI periode 2014-2018 diukur dengan PBV

\begin{tabular}{lllllll}
\hline \multirow{2}{*}{ No. } & \multirow{2}{*}{ Kode Emiten } & \multicolumn{5}{c}{ PBV (Firm Value) } \\
\cline { 3 - 7 } & & 2014 & 2015 & 2016 & 2017 & 2018 \\
\hline 1 & AKRA & 2,84 & 4,03 & 3,06 & 2,82 & 1,80 \\
2 & ASII & 2,6 & 1,92 & 2,54 & 2,15 & 1,98 \\
3 & BBCA & 4,33 & 3,8 & 3,49 & 4,11 & 4,46 \\
4 & ICBP & 5,26 & 4,79 & 5,61 & 5,11 & 5,56 \\
5 & INDF & 1,45 & 1,05 & 1,55 & 1,43 & 1,35 \\
6 & UNTR & 1,68 & 1,61 & 1,97 & 2,78 & 1,87 \\
7 & UNVR & 45,03 & 48,48 & 46,67 & 82,44 & 38,62 \\
\hline
\end{tabular}

Sumber: Data Penelitian, 2019

Tabel 1. dapat dilihat bahwa adanya permasalahan nilai perusahaan pada indeks saham LQ45 yang berfluktuasi. Fluktuasi yang terjadi pada nilai perusahaan

membuat ketidakpastian keuntungan yang dapat diperoleh pemegang saham. Hal ini menjadi isu pokok dalam pelaksanaan penelitian. Bagi perusahaan yang sudah go public, nilai perusahaan dianggap penting karena dapat meningkatkan daya tarik investor untuk berinvestasi pada perusahaan. Harga saham yang tinggi akan mencerminkan nilai perusahaan yang tinggi serta akan berdampak pada kemakmuran pemegang saham.

Kasus yang dikutip dari finance.detik.com, turunnya laba bersih PT. Adoro Energy Tbk. (ADRO) dilihat dari laporan keuangan yang dirilis sepanjang tahun 2018. Sepanjang 2018, laba bersih emiten berkode saham ADRO sebesar US\$ 
417,72 juta atau setara Rp 5,84 triliun. Angka itu turun 13,56\% dari perolehan laba bersih ADRO di 2017 sebesar US\$ 483,23 juta. Selain ADRO, Apple juga mengalami penurunan menjadi US\$ 142,19 atau setara dengan Rp 2 Juta per lembar saham (pada kurs Rp 14.500). Jumlah ini turun 39\% dari angka saham tertinggi yang pernah dicapai Apple. Sejak Oktober lalu, saham Apple memiliki tren yang buruk dan terus menurun. Mengutip dari CNBC, Jumat (4/1/2019), sebelumnya Apple pernah mencatatkan angka tertinggi dalam 52 minggu menembus angka US\$ 233,47 atau setara dengan Rp 3 Juta per lembar saham. Karena anjloknya harga saham Apple tersebut, perusahaan ini telah kehilangan US\$ 452 miliar setara dengan Rp 6.554 triliun dalam kapitalisasi pasar sejak 3 Oktober 2018.

Profitabilitas menunjukkan kemampuan suatu perusahaan menghasilkan laba selama periode tertentu, penilaian terhadap profitabilitas pada suatu perusahaan dapat dilakukan salah satunya dengan cara menggunakan Return on Assets (ROA) (Sugiyarso \& F, 2005 :111). Return on Assets (ROA) yang mengukur kemampuan dari modal yang diinvestasikan dalam keseluruhan aktiva untuk menghasilkan keuntungan neto. Perusahaan didirikan tidak hanya sekedar untuk meraih laba sebesar-besarnya, tetapi juga bertujuan untuk meningkatkan kemakmuran pihak-pihak yang berkaitan dengan kegiatan usaha perusahaan (Atmaja \& Astika, 2018).

Kebijakan dividen sering dianggap sebagai sinyal bagi investor dalam menilai baik buruknya kinerja suatu perusahaan serta menjadi sumber pendapatan bagi investor (Iqbal, 2012). Kebijakan dividen merupakan keputusan mengenai laba yang diperoleh perusahaan yang akan dibagikan kepada pemegang saham sebagai dividen atau ditahan sebagai laba ditahan untuk pembiayaan masa yang akan datang. Adanya dividen akan menambah kekayaan pemegang saham (Adesola, 2009). Struktur modal merupakan pendanaan perusahaan yang bersumber dari internal maupun dari eksternal perusahaan untuk membiayai kegiatan operasional perusahaan. Sumber dana internal berupa laba yang ditahan dan depresiasi, sedangkan sumber dana eksternal berupa hutang jangka panjang dan modal sendiri.

Struktur modal diproksikan dengan Debt to Equity Ratio (DER) karena dapat melihat penggunaan pendanaan perusahaan. Pemilihan struktur modal akan menentukan jumlah hutang yang digunakan untuk pembiayaan perusahaan. Penelitian (Pratama \& Wirawati, 2016) menemukan profitabilitas dan struktur modal berpengaruh positif terhadap nilai perusahaan. Penelitian (Ju Chen, Li \& Yu Chen, 2011) menemukan bahwa profitabilitas berpengaruh terhadap nilai perusahaan. Penelitian (Andriza \& Yusra, 2019) menemukan kebijakan dividen berpengaruh positif terhadap nilai perusahaan. Penelitan (Oktaviani, Rosmaniar, \& Hadi, 2019) menemukan bahwa struktur modal berpengaruh positif terhadap nilai perusahaan.

Perbedaan penelitian ini dengan penelitian sebelumnya adalah objek penelitian serta kurun waktu penelitian. Peneliti menggunakan perusahaan yang termasuk dalam indeks saham LQ45 karena tidak banyak yang menggunakan perusahaan LQ45 sebagai objek penelitian. Perusahaan yang tergabung dalam kelompok LQ45 memiliki kapitalisasi pasar yang paling likuid tetapi nilai perusahaan yang diukur melalui proksi Price to Book Value (PBV) 
mengalami fluktuasi. Hal ini menarik minat peneliti untuk meneliti lebih lanjut mengenai bagaimana pengaruh profitabilitas, kebijakan dividen, dan struktur modal pada nilai perusahaan kelompok indeks saham LQ45 yang terdaftar di Bursa Efek Indonesia (BEI).

Rumusan masalah dalam penelitian ini adalah apakah profitabilitas, kebijakan dividen, struktur modal berpengaruh pada nilai perusahaan?. Tujuan penelitian ini adalah untuk memperoleh bukti empiris mengenai pengaruh profitabilitas, kebijakan dividen, struktur modal berpengaruh pada nilai perusahaan. Penelitian ini diharapkan dapat memberikan manfaat baik manfaat teoretis dan manfaat praktis. Manfaat teoretis diharapkan dapat memberikan tambahan referensi penelitian mengenai pengaruh profitabilitas, kebijakan dividen, struktur modal pada nilai perusahaan serta teori sinyal, bird in the hand theory, dan trade off theory. Manfaat praktis bagi manajemen, diharapkan hasil penelitian ini dapat memberikan pertimbangan serta konsep baru dalam manajemen. Bagi akademis diharapkan penelitian ini dapat memberikan bukti empiris serta dapat menambah wawasan dan pengetahuan yang lebih mendalam bagi para akademis. Bagi investor diharapkan penelitian ini dapat menjadi pertimbangan dalam pengambilan keputusan bagi para calon investor yang ingin berinvestasi.

Teori sinyal merupakan bagian dari teori struktur modal yang dikembangkan oleh Modigliani dan Merton Melly pada tahun 1958 (Brigham, Eugene F. \& Houston, 2011). Teori sinyal menyatakan tentang bagaimana sebuah perusahaan seharusnya memberikan sinyal kepada pengguna laporan keuangan guna mendapatkan informasi prospek perusahaan. Menurut (Pertiwi, 2018) sinyal adalah suatu tindakan yang diambil oleh manajemen perusahaan yang memberikan petunjuk bagi investor tentang bagaimana manajemen memandang prospek perusahaan. Kondisi ketidakpastian informasi dari pihak luar mengenai informasi dan prospek perusahaan, investor akan melindungi diri dengan melakukan permintaan penawaran harga yang lebih rendah dari yang ditawarkan entitas. Bagaimanapun nilai perusahaan dapat ditingkatkan jika manajemen secara sukarela melaporkan (memberikan sinyal) informasi privat tentang entitas yang dikelolanya secara kredibel sehingga mengurangi ketidakpastian yang dihadapi oleh pihak luar mengenai prospek masa depan investasinya (Astika, $2010: 79$ ).

Teori bird in the hand menjelaskan bahwa pembayaran dividen yang tinggi lebih diharapkan sesuai tujuan investor menanamkan saham untuk mendapatkan penerimaan berupa dividen. Gordon \& Lintner (1956) mengatakan bahwa investor lebih menyukai dividen tunai daripada imbal hasil yang dijanjikan atas investasi atau yang disebut dengan capital gain dimasa mendatang. Teori bird in the hand menjelaskan bahwa pembayaran dividen yang tinggi lebih diharapkan sesuai tujuan investor menanamkan saham untuk mendapatkan penerimaan berupa dividen.

Trade off theory adalah teori struktur modal yang menyatakan bahwa perusahaan menukar manfaat pajak dari pendanaan utang dengan masalah yang ditimbulkan oleh potensi kebangkrutan (Brigham, Eugene F. \& Houston, 2011 : 183). Menurut Lestari (2019), konsep Trade off dalam Balancing Theory adalah 
menyeimbangkan manfaat dan biaya dari penggunaan hutang dalam struktur modal sehingga disebut sebagai Trade off Theory. Penggunaan hutang yang semakin besar akan meningkatkan nilai perusahaan. Kepailitan dalam arti bangkrut terjadi ketika total kewajiban melebihi penilaian wajar dari asset perusahaan dengan nilai yang ditentukan oleh kekuatan penghasilan asset (Cheng \& Tzeng, 2011). Penyeimbangan pada penghematan pajak atas penggunaan hutang terhadap biaya kebangkrutan dapat membentuk struktur modal yang optimal. Struktur modal dan nilai perusahaaan diprediksikan memiliki hubungan positif menurut trade off theory dengan asumsi keuntungan pajak masih lebih besar dari biaya kepailitan dan biaya keagenan.

Teori sinyal menyatakan bagaimana sebuah perusahaan memberikan sinyal - sinyal informasi kepada investor mengenai laporan keuangan perusahaan. Informasi yang didapat investor salah satunya adalah informasi kinerja keuangan perusahaan yang diukur menggunakan rasio profitabilitas. Rasio profitabilitas diproksikan melalui Return on Assets (ROA). Investor akan tertarik pada perusahaan yang memiliki profit cenderung meningkat sebagai sinyal positif untuk menanamkan modalnya. Profitabilitas mencerminkan laba dari investasi keuangan (Sabrin, Sarita, .S, \& Sujono, 2016). Profitabilitas memiliki pengaruh positif pada nilai perusahaan karena semakin tinggiprofitabilitas maka semakin tinggi nilai perusahaan. Penelitian yang dilakukan Cahyani, (2019) mengatakan profitabilitas berpengaruh positif terhadap nilai perusahaan selaras dengan penelitian Putra (2017) dan Wijaya \& Sedana (2015). Maka hipotesis penelitian, yaitu.

$\mathrm{H}_{1}$ : Profitabilitas berpengaruh positif pada Nilai Perusahaan.

Teori sinyal menekankan pada sinyal positif yang diberikan perusahaan kepada investor. Sinyal positif yang diberikan berupa kebijakan dividen perusahaan dalam pembayaran dividen kepada para pemegang saham sebagai bentuk apresiasi terhadap para pemegang saham. Pembayaran dividen pada hakikatnya merupakan komunikasi secara tidak langsung kepada para pemegang saham tentang profitabilitas yang dicapai perusahaan (Halim, 2015 : 71). Kenaikan pembagian dividen yang dilihat oleh investor akan dilihat sebagai sinyal bahwa prospek perusahaan dimasa mendatang itu baik (Iqbal, 2012). Pembayaran berupa dividen kepada para investor sejalan dengan teori bird in the hand yang menyatakan bahwa investor lebih mengharapkan pengembalian dalam bentuk dividen daripada imbal hasil yang dijanjikan atas investasi (capital gain). Kebijakan dividen mempengaruhi kekayaan pemegang saham dan penilaian perusahaan (Agila, 2018). Investor dapat menilai kebijakan dividen perusahaan melalui Dividend Payout Ratio (DPR) yang menunjukkan seberapa besar porsi keuntungan yang dibagikan oleh perusahaan untuk dijadikan dividen. Kebijakan dividen berimplikasi positif pada nilai perusahaan karena semakin baik kebijakan dividen perusahaan, maka semakin baik pula nilai perusahaan. Penelitian Andriza \& Yusra (2019) mengatakan bahwa kebijakan dividen berpengaruh positif terhadap nilai perusahaan selaras dengan Apsari \& Setiawan (2018) dan Wijaya \& Sedana (2015). Maka hipotesis penelitian, yaitu.

$\mathrm{H}_{2}$ : Kebijakan Dividen berpengaruh positif pada Nilai Perusahaan. 
Trade off theory dikemukakan oleh Myers (1984) the static trade off hypothesis. Teori trade-off dari leverage adalah teori yang menjelaskan bahwa struktur modal yang optimal ditemukan dengan menyeimbangkan manfaat dari pendanaan dengan hutang (perlakukan pajak perseroan yang menguntungkan) dengan suku bunga dan kebangkrutan yang lebih tinggi (Yanda, 2018). Utang yang dimiliki perusahaan berhubungan dengan keuntungan yang akan diperoleh perusahaan (Keshtavar et al., 2013). Penentuan struktur modal yang baik membantu perusahaan dalam mengelola sumber pendanaan untuk pengambilan keputusan investasi yang tepat. Teori trade-off memprediksikan adanya pengaruh positif struktur modal terhadap nilai perusahaan, dikarenakan keuntungan pajak masih lebih besar dari pada biaya tekanan financial dan biaya keagenan. Penelitian Oktaviani, Rosmaniar, \& Hadi (2019) mengatakan struktur modal berpengaruh positif terhadap nilai perusahaan selaras dengan (Yanda, 2018) dan Pratama \& Wirawati (2016). Maka hipotesis penelitian, yaitu.

$\mathrm{H}_{3}$ : Struktur Modal berpengaruh positif pada Nilai Perusahaan.

\section{METODE PENELITIAN}

Populasi dalam penelitian ini adalah seluruh perusahaan yang pernah tercatat dalam indeks LQ45 pada tahun 2014-2018. Metode penentuan sampel yang digunakan adalah purposive sampling. Variabel bebas dalam penelitian ini adalah profitabilitas $\left(X_{1}\right)$, kebijakan dividen $\left(X_{2}\right)$, dan struktur modal $\left(X_{3}\right)$. Variabel terikat dalam penelitian ini adalah nilai perusahaan $(\mathrm{Y})$.

Nilai perusahaan adalah nilai yang tercermin dari nilai pasar sahamnya jika perusahaan tersebut sudah go public, jika belum go public maka nilai perusahaan adalah nilai yang terjadi apabila perusahaan tersebut dijual (Aziza, 2016). Price to Book Value (PBV) merupakan rasio antara harga per saham dibagi nilai buku per saham (Ross et al., 2016:16). Penelitian Yanda (2018), rasio profitabilitas yang diproksikan melalui Price to Book Value (PBV) dihitung dengan cara sebagai berikut.

$\mathrm{PBV}=\frac{\text { Harga Saham }}{\text { Nilai Buku Saham }} \times 100 \%$

Profitabilitas adalah indikator pencapaian tujuan perusahaan dalam memperoleh laba. Profitabilitas sangat penting untuk perusahaan apabila akan membagikan dividen karena profitabilitas diartikan sebagai kemampuan perusahaan untuk menghasilkan laba atau profit dalam upaya meningkatkan nilai perusahaan (Gryglewicz, 2011). Penelitian ini menggunakan rasio profitabilitas yang diproksikan dengan Return on Assets (ROA). Rasio ini mengukur kemampuan perusahaan memperoleh laba dengan menggunakan total aktiva yang dimiliki sehingga pemegang saham mendapatkan informasi keefektifan perusahaan dalam mengelola perusahaannya. Menurut Hoyt \& Libenberg (2007), ROA dihitung dengan laba bersih dibagi dengan total aktiva sebagai berikut.

ROA $=\frac{\text { Laba Bersih }}{\text { Total Aktiva }} \times 100 \%$

Kebijakan dividen merupakan kebijakan pembayaran laba perusahaan kepada para pemegang saham perusahaan yang sebanding dengan jumlah lembar saham yang dimiliki pada perusahaan (Senata, 2016). Kebijakan dividen 
memengaruhi kemampuan perusahaan secara signifikan untuk mengumpulkan uang dan nilainya (Sorin, 2016). Kebijakan dividen sering dianggap sebagai sinyal bagi investor dalam menilai baik buruknya kinerja suatu perusahaan serta menjadi sumber pendapatan bagi investor (Khan et al., 2011). Kebijakan dividen pada penelitian ini diukur menggunakan rasio Devidend Payout Ratio (DPR). Menurut Pertiwi (2018), Devidend Payout Ratio (DPR) yakni rasio yang menggambarkan persentase laba yang diberikan oleh perusahaan kepada para pemegang saham dalam bentuk dividen dan DPR dapat dihitung dengan cara sebagai berikut.

DPR $=\frac{\text { Dividen } \text { per share }}{\text { Earning per share }} \times 100 \%$

Menurut Gitman (2010 : 53) struktur modal merupakan salah satu area keputusan keuangan karena terdapat hubungan dengan variabel-variabel struktur modal, dimana struktur modal yang baik adalah dengan biaya modal yang murah dan sebaliknya struktur modal yang tidak bagus adalah biaya modal yang sangat tinggi. Semakin tinggi hutang perusahaan, maka perusahaan tersebut akan semakin dinamis (Dira \& Astika, 2014). Kebijakan terhadap struktur modal sangat penting karena berdampak pada utang dan ekuitas. Semakin tinggi penggunaan utang dibandingkan modal maka akan semakin tinggi pula risiko yang akan ditanggung. Struktur modal diproksikan dengan Debt to Equity Ratio (DER) yang mengungkapkan bagaimana penggunaan pendanaan perusahaan dari struktur modal yang dimiliki oleh perusahaan yang berasal dari utang jangka panjang dan modal yang berasal dari ekuitas (Ircham, Handayani, \& Saifi, 2014). Menurut Anggraini (2019) Debt to Equity Ratio (DER) dihitung menggunakan rumus sebagai berikut.

$$
\text { DER }=\frac{\text { Total Kewajiban }}{\text { Total Modal }} \times 100 \%
$$

Metode pengumpulan data yang digunakan adalah observasi dan studi pustaka dengan pendekatan kuantitatif berbentuk asosiatif. Berdasarkan sumbernya, penelitian ini menggunakan data sekunder yaitu laporan keuangan terpublikasi oleh perusahaan LQ45 yang terdaftar di BEI pada tahun 2014-2018 yang diakses melalui website www.idx.co.id.

\section{HASIL DAN PEMBAHASAN}

Data penelitian ini diperoleh dengan mengunduh laporan keuangan perusahaan LQ45 yang terdaftar di Bursa Efek Indonesia (BEI) tahun 2014 - 2018. Sampel pada penelitian ini menggunakan metode pusposive sampling, sehingga sampel yang dipilih merupakan representasi dari populasi yang sesuai dengan tujuan penelitian. Tahap pemilihan sampel dilakukan berdasarkan kriteria, disajikan dalam Tabel 2.

Berdasarkan hasil dari proses seleksi sampel yang dilihat pada Tabel 2. diperoleh perusahaan sebagai sampel penelitian pada tahun 2014 - 2018 adalah sebanyak 6 perusahaan LQ45, sehingga jumlah observasi dalam penelitian selama tahun 2014 - 2018 adalah 30 amatan. 
Tabel 2. Tahap Pemilihan Sampel

\begin{tabular}{|c|c|c|}
\hline No. & Kriteria & Akumulasi \\
\hline & $\begin{array}{l}\text { Populasi seluruh perusahaan yang pernah tercatat } \\
\text { dalam indeks LQ45 pada tahun } 2014 \text { - } 2018\end{array}$ & 68 \\
\hline 1 & $\begin{array}{l}\text { Perusahaan yang tidak konsisten terdaftar pada } \\
\text { perusahaan LQ45 serta mempublikasikan laporan } \\
\text { keuangan di Bursa Efek Indonesia (BEI) pada tahun } \\
2014 \text { - } 2018 \text {. }\end{array}$ & (42) \\
\hline 2 & $\begin{array}{l}\text { Perusahaan yang tidak membagikan dividen } \\
\text { berturut - turut selama periode } 2014 \text { - } 2018\end{array}$ & (19) \\
\hline \multirow[t]{3}{*}{3} & Data Outlier & (1) \\
\hline & Jumlah perusahaan yang dijadikan sampel & 6 \\
\hline & $\begin{array}{l}\text { Jumlah observasi selama tahun } 2014-2018 \\
(6 \times 5 \text { tahun })\end{array}$ & 30 \\
\hline
\end{tabular}

Sumber: Data Penelitian, 2019

Sebelum pengolahan data, didahului dengan melakukan pendeteksian adanya data outlier. Outlier adalah data yang memiliki karakteristik unik yang terlihat sangat berbeda jauh dari observasi - observasi lainnya dan muncul dalam bentuk nilai ekstrim baik untuk sebuah variabel tunggal atau kombinasi (Ghozali, 2016 : 41). Menurut Ghozali (2016 : 41) terdapat empat penyebab timbulnya data outlier, yaitu kesalahan dalam mengentri data, gagal menspesifikasi adanya missing value dalam program komputer, outlier bukan merupakan anggota populasi yang diambil sebagai sampel, dan distribusi dari variabel dalam populasi tersebut memiliki nilai ekstrim dan tidak berdistribusi secara normal.

Tabel 3. Hasil Statistik Deskriptif Variabel Penelitian

\begin{tabular}{llllll}
\hline & N & Minimum & Maximum & Mean & Std. Deviation \\
\hline PBV & 30 & 1.05 & 5.61 & 2.9667 & 1.40845 \\
ROA & 30 & 2.32 & 12.56 & 6.8180 & 2.87030 \\
DPR & 30 & 7.53 & 66.68 & 36.3903 & 18.55985 \\
DER & 30 & .50 & 6.06 & 1.5743 & 1.66676 \\
Valid N (listwise) & 30 & & & &
\end{tabular}

Sumber: Data Penelitian, 2019

Nilai perusahaan $(Y)$ memiliki nilai terendah (minimum) sebesar 1,05 pada perusahaan Indofood Sukses Makmur Tbk. berkode saham INDF tahun 2015 dan nilai tertinggi (maksimum) sebesar 5,61 pada perusahaan Indofood CBP Sukses Makmur Tbk. berkode saham ICBP tahun 2016. Nilai rata rata (mean) data variabel PBV sebesar 2.9667. Standar deviasi sebesar 1,40845. Profitabilitas $\left(X_{1}\right)$ memiliki nilai terendah (minimum) sebesar 2,32 pada perusahaan Bank Central Asia Tbk. berkode saham BBCA tahun 2018 dan nilai tertinggi (maksimum) sebesar 12,56 pada perusahaan Indofood CBP Sukses Makmur Tbk. berkode saham ICBP tahun 2016. Nilai rata - rata (mean) rasio Return on Asset (ROA) sebesar 6,8180. Standar deviasi sebesar 2,87030. Kebijakan Dividen $\left(\mathrm{X}_{2}\right)$ memiliki nilai terendah (minimum) sebesar 7,53 pada perusahaan Bank Central Asia Tbk. berkode saham BBCA tahun 2015 dan nilai tertinggi (maksimum) sebesar 66,68 pada perusahaan AKR Corporindo Tbk. berkode saham AKRA tahun 2017. Nilai rata - rata (mean) rasio Dividend Payout Ratio (DPR) sebesar 36,3903 dan standar deviasi sebesar 18,55985. Struktur Modal 
$\left(X_{3}\right)$ memiliki nilai terendah (minimum) sebesar 0,50 pada perusahaan United Tractors Tbk. berkode saham UNTR tahun 2016 dan nilai tertinggi (maksimum) sebesar 6,06 pada perusahaan Bank Central Asia Tbk. berkode saham BBCA tahun 2016. Nilai rata - rata (mean) rasio Debt to Equity Ratio (DER) sebesar 1,5743 dan standar deviasi sebesar 1,66676.

Hasil uji normalitas pada persamaan regresi linear berganda menunjukkan bahwa nilai Asymp. Sig (2-tailed) 0,823 lebih besar dari level of significant, yaitu 5 persen $(0,05)$. Jadi dapat disimpulkan bahwa nilai residual pada model regresi yang diuji sudah berdistribusi normal. Berdasarkan hasil uji multikolinearitas bahwa nilai VIF dan Tolerance, dari seluruh variabel memiliki nilai Tolerance yang lebih dari 0,1 (10 persen) ataupun nilai VIF yang kurang dari 10. Berdasarkan hasil uji multikolinearitas nilai Tolerance dan VIF pada model analisis tersebut tidak ditemukan adanya gejala multikoli-

nearitas, sehingga model regresi penelitian ini layak untuk dianalisis lebih lanjut karena terbebas dari korelasi antar variabel bebas. Hasil uji heteroskedastisitas menunjukkan bahwa nilai signifikansi Return on Assets (ROA) $\left(\mathrm{X}_{1}\right)$ sebesar 0,154, Kebijakan Dividen (DPR) $\left(\mathrm{X}_{2}\right)$ sebesar 0,685, dan Struktur Modal (DER) $\left(\mathrm{X}_{3}\right)$ sebesar 0,123. Hasil uji tersebut memiliki nilai yang lebih besar dari $a=0.05$. Oleh karena itu, dapat disimpulkan bahwa model regresi dalam penelitian tidak terjadi heteroskedastisitas. Hasil uji autokerolasi menunjukkan bahwa besarnya nilai Durbin Watson sebesar 2,188. Nilai D-W menurut tabel dengan $\mathrm{n}=30$ dan $\mathrm{k}=3$ didapat nilai $\mathrm{dl}=1,2138$ dan nilai $\mathrm{du}=1,6498$. Oleh karena nilai $\mathrm{du}<\mathrm{dw}<(4-\mathrm{du})$ yaitu $(1,6498<2,188<2,350)$, maka dapat disimpulkan bahwa model regresi dalam penelitian tidak terdapat autokorelasi antar residual.

Tabel 4. Hasil Uji Analisis Regresi Linear Berganda



Sumber: Data Penelitian, 2019

Dari hasil analisis regresi linear berganda pada Tabel 4. tersebut, maka dapat dibuat persamaan sebagai berikut:

$$
Y=-0,041+0,627 X_{1}+0,311 X_{2}+0,496 X_{3}
$$

Nilai konstanta sebesar $-0,041$ memiliki arti bahwa apabila variabel konstan (tetap atau tidak ada perubahan) sebesar 0 , maka variabel Y sama dengan - 0,041. Nilai koefisien $X_{1}=0,627$ menunjukkan apabila mengalami kenaikan satu persen, maka variabel $\mathrm{Y}$ akan mengalami kenaikan sebesar 62,7 persen dengan asums bahwa variabel independen lain konstan. Nilai koefisien $\mathrm{X}_{2}=0,311$ menunjukkan apabila mengalami kenaikan satu persen, maka variabel $\mathrm{Y}$ akan mengalami kenaikan sebesar 31,1 persen dengan asumsi bahwa variabel independen lain konstan. Nilai koefisien $X_{3}=0,496$ menunjukkan apabila mengalami kenaikan satu persen, maka variabel Yakan 
mengalami kenaikan sebesar 49,6 persen dengan asumsi bahwa variabel independen lain konstan.

Nilai profitabilitas $\left(X_{1}\right)$, kebijakan dividen $\left(X_{2}\right)$, struktur modal $\left(X_{3}\right)$ memiliki niali signifikan uji $t$ kurang dari 0,050 berarti ketiga varibael memiliki pengaruh signifikan pada nilai perusahaan (Y). Hasil uji $\mathrm{F}$ ( $F$ test) menunjukkan bahwa nilai $F$ hitung sebesar 15,632 dengan nilai signifikansi $\mathrm{P}$ value 0,000 yang lebih kecil dari $\alpha=0,05$, ini berarti model yang digunakan pada penelitian ini adalah layak. Hasil ini memberikan makna bahwa ketiga variabel independen mampu memprediksi atau menjelaskan fenomena nilai perusahaan yang diproksikan dengan Price to Book Value (PBV) pada perusahaan LQ45 yang terdaftar di BEI selama periode 2014-2018. Hasil uji koefisien determinasi memberikan hasil dimana diperoleh besarnya adjusted $\mathrm{R}^{2}$ (koefisien determinasi yang telah disesuaikan) adalah sebesar 0,602. Ini berarti sebesar 60,2 persen variasi nilai Price to Book Value (PBV) dapat dipengaruhi secara signifikan oleh variabel Return on Assets (ROA) $\left(\mathrm{X}_{1}\right)$, Dividend Payout Ratio (DPR) $\left(\mathrm{X}_{2}\right)$, dan Debt to Equity Ratio (DER) $\left(\mathrm{X}_{3}\right)$, sedangkan sisanya sebesar 39,8 persen dijelaskan oleh faktor-faktor lain yang tidak dijelaskan dalam model penelitian. Hasil uji hipotesis (uji $t$ ) menunjukkan nilai signifikan $X_{1}=$ $0,000, X_{2}=0,016$, dan $X_{3}=0,000$ lebih kecil dari $a=0,05$ yang berarti variabel independen berpengaruh signifikan secara serempak bersama sama pada variabel dependen, sehingga model layak diteliti.

Hipotesis pertama menunjukkan bahwa profitabilitas yang diproksikan dengan Return on Asset (ROA) pada nilai perusahaan yang diproksikan dengan Price to Book Value (PBV) berpengaruh positif signifikan sehingga $\mathrm{H}_{0}$ ditolak dan $\mathrm{H}_{1}$ diterima. Hal ini ditunjukkan dengan koefisien regresi ROA sebesar 0,627 dengan nilai signifikansi 0,000 lebih kecil dari tingkat signifikansi sebesar 0,05. Profitabilitas yang tinggi dan stabil akan menjadi sinyal positif bagi investor terkait kinerja perusahaan yang mencerminkan prospek perusahaan di masa mendatang. Hasil penelitian ini sejalan dengan hasil penelitian yang dilakukan oleh Cahyani (2019), Ju Chen, Li \& Yu Chen (2011), Armadi \& Astika (2016) dan Anggraini (2019) menyatakan bahwa profitabilitas berpengaruh positif pada nilai perusahaan.

Hipotesis kedua menunjukkan bahwa kebijakan dividen yang diproksikan dengan Dividen Payout Ratio (DPR) pada nilai perusahaan yang diproksikan dengan Price to Book Value (PBV) berpengaruh positif signifikan sehingga $\mathrm{H}_{0}$ ditolak dan $\mathrm{H}_{2}$ diterima. Hal ini ditunjukkan dengan koefisien regresi DPR sebesar 0,311 dengan nilai signifikan 0,016 lebih kecil dari tingkat signifikansi sebesar 0,05. Pembayaran dividen menjadi sinyal kesehatan keuangan perusahaan yang mengindikasikan bahwa manajemen mampu mengelola perusahaan untuk mendapatkan keuntungan serta manajemen mampu memberikan kebijakan yang baik dan tepat dalam membagikan jumlah dividen kepada investor. Hasil penelitian ini sejalan dengan hasil penelitian yang dilakukan Andriza \& Yusra (2019), Octaviani \& Astika (2016), serta Pertiwi (2018) yang menyatakan bahwa kebijakan dividen berpengaruh positif pada nilai perusahaan.

Hipotesis ketiga menunjukkan bahwa struktur modal yang diproksikan dengan Debt to Equity Ratio (DER) pada nilai perusahaan yang diproksikan 
dengan Price to Book Value (PBV) berpengaruh positif sehingga $\mathrm{H}_{0}$ ditolak dan $\mathrm{H}_{3}$ diterima. Hal ini ditunjukkan dengan koefisien regresi DER sebesar 0,496 dengan nilai signifikansi 0,000 lebih kecil dari tingkat signifikansi sebesar 0,05. Pengoptimalan struktur modal perusahaan dengan menggunakan hutang sebagai modal dalam operasional perusahaan dapat membantu meningkatkan nilai perusahaan. Jensen (1986) dalam Dewi \& Wirasedana (2018) menyatakan bahwa dengan adanya hutang dapat digunakan untuk mengendalikan penggunaan free cash flow secara berlebihan oleh manajemen yang dapat menghindari investasi sia- sia, dengan demikian akan meningkatkan nilai perusahaan. Hasil penelitian ini sejalan dengan hasil penelitian yang dilakukan oleh Oktaviani et al., (2019), Pratama \& Wirawati (2016), serta Puspita \& Hermuningsih (2019) yang menyatakan bahwa struktur modal berpengaruh positif pada nilai perusahaan.

\section{SIMPULAN}

Berdasarkan hasil penelitian yang telah diperoleh melalui pengujian statistik dan pembahasan yang telah diuraikan pada bab sebelumnya, maka dapat disimpulkan bahwa profitabilitas berpengaruh positif pada nilai perusahaan. Kebijakan dividen berpengaruh positif pada nilai perusahaan. Struktur modal berpengaruh positif pada nilai perusahaan. Bagi pihak manajemen perusahaan yang ingin meningkatkan nilai perusahaan dapat mempertimbangkan faktor - faktor profitabilitas, kebijakan dividen, dan struktur modal karena nilai perusahaan yang tinggi akan menarik minat investor untuk berinvestasi. Bagi pihak investor yang ingin berinvestasi dapat mempertimbangkan

faktor faktor profitabilitas, kebijakan dividen, dan struktur modal untuk pengambilan keputusan sebelum berinvestasi. Bagi pihak peneliti selanjutnya yang tertarik untuk melakukan penelitian sejenis, disarankan untuk melakukan perluasan penelitian. Pengamatan dalam penelitian seperti rentan waktu disarankan untuk diperpanjang agar menghasilkan hasil yang lebih akurat.

\section{REFERENSI}

Adesola, WA, and A. O. (2009). An Imperical Study of Divident Policy of Quoted Companies in Nigeria. Global Journal of Social Sciences, 8(1), pp:85-101. Retrieved from http://www.ajol.info/index.php/gjss/article/view/48907

Agila.M, D. M. J. . (2018). Dividend Policy and its Impact on Shareholder's Wealth and Firm Performance: A Study of Listed Cement Companies. IOSR Journal of Business and Management (IOSR-JBM), 20(9), 28-31. https:/ / doi.org/10.9790/487X-2009072831

Andriza, R., \& Yusra, I. (2019). Pengaruh Kepemilikan Manajerial Dan Kebijakan Deviden Terhadap Kemakmuran Investor Dan Nilai Perusahaan Yang Tercatat Pada Indeks LQ45. INA-Rxiv.

Anggraini, A. (2019). Pengaruh Profitabilitas, Ukuran Perusahaan dan Growth Opportunity Terhadap Nilai Perusahaan dengan Struktur Modal Sebagai Variabel Intervening (Studi Kasus pada Perusahaan Manufaktur Sub Sektor Makanan dan Minuman yang terdaftar di BEI periode 2013-2017). Statistika Industri Dan Komputasi, 4(1), 15-30. 
Apsari, L., \& Setiawan, P. E. (2018). Pengaruh Tax Avoidance terhadap Nilai Perusahaan dengan Kebijakan Dividen sebagai Variabel Moderasi. E-Jurnal Akuntansi, 23, 1765. https:// doi.org/10.24843/eja.2018.v23.i03.p06

Armadi, I. W., \& Astika, P. (2016). Pengaruh Profitabilitas, Leverage Dan Ukuran Perusahaan Pada Nilai Perusahaan Melalui Pengungkapan Tanggung Jawab Sosial. E-Jurnal Akuntansi, 17(1), 233-256.

Astika, P. (2010). Konsep - Konsep Dasar Akuntansi Keuangan. Denpasar: Udayana University Press.

Atmaja, I. G. N. Y. D., \& Astika, I. B. P. (2018). Pengaruh Profitabilitas, Leverage, Dan Modal Kerja Pada Nilai Perusahaan Dengan CSR Sebagai Variabel Intervening.

E-Jurnal

Akuntansi. https://doi.org/10.24843/eja.2018.v24.i01.p01

Aziza, S. A. (2016). Pengaruh Free Cash Flow, Dividend, Leverage Dan Good Corporate Governance Terhadap Nilai Perusahaan Pada Perusahaan Manufaktur Yang Terdaftar Di Bursa Efek Indonesia. Journal Riset Mahasiswa Akuntansi (JRMA), Vol.4 No.2(ISSN: 2337), 1-11.

Brigham, Eugene F. dan Houston, J. F. (2011). Dasar-dasar Manajemen Keuangan Terjemahan (10th ed.). Jakarta: Salemba Empat.

Cahyani, G. A. P. (2019). Pengaruh Likuiditas, Kebijakan Dividen, Profitabilitas, dan Ukuran Perusahaan pada Nilai Perusahaan. E-Jurnal Akuntansi Universitas Udayana, 27(02), 1263-1289.

Cheng, M.-C., \& Tzeng, Z.-C. (2011). The Effect of Leverage on Firm Value and How The Firm Financial Quality Influence on This Effect. World Journal of Management, 3(2), 30-53. https:/ / doi.org/10.1142/s0219091514500040

Dewi, L. P. U. K., \& Wirasedana, I. W. P. (2018). Pengaruh Keputusan Investasi, Keputusan Pendanaan, Kebijakan Dividen dan Tingkat Inflasi Terhadap Nilai Perusahaan. Fakultas Ekonomi Dan Bisnis Universitas Udayana (Unud), Bali, Indonesia, 23, 1-29.

Dira, K., \& Astika, P. (2014). Pengaruh Struktur Modal, Likuiditas, Pertumbuhan Laba, Dan Ukuran Perusahaan Pada Kualitas Laba. E-Jurnal Akuntansi, 7(1), 64-78.

Fama, dan K. R. F. (1998). Taxes, Financing Decision, and Firm Value. The Journal of Finance LIII, June(3), 819-843.

Finance, D. (n.d.). Laba Bersih Adaro Turun 13,56\% Jadi Rp 5,84 T. Retrieved April 28, 2019, from https://finance.detik.com/bursa-dan-valas/d4454032/laba-bersih-adaro-turun-1356-jadi-rp-584-t

Ghozali, I. (2016). Aplikasi Analisis Multivariate Dengan Program IBM SPSS 21 (8th ed.) (Vol. 21). Retrieved from https://www.coursehero.com/file/p3er64f/Ghozali-Imam-2016-AplikasiAnalisis-Multivariate-Dengan-Program-IBM-SPSS-21/

Gitman, L. J. (2010). Principles of Management Finance (Thirteenth). Pearson Education.

Gordon, \& Lintner, J. (1956). Distribution Of Incomes Of Corporations Among Dividens, Retained Earnings and Taxes. The American Economic Review, 46, 97-113.

Gryglewicz, S. (2011). A Theory of Corporate Financial Decisions with Liquidity and Solvency Concerns. Journal of Financial Economics, 99(2), 365-384. 
Retrieved from /

Halim, A. (2015). Analisis Investasi dan Aplikasinya: Dalam Aset Keuangan dan Aset Riil. Jakarta: Salemba Empat.

Hoyt, R. E., \& Libenberg, A. P. (2007). The Value of Enterprise Risk Management The Value of Enterprise Risk Management Abstract. Journal of Risk and Insurance, 00(0), no-no. https:// doi.org/10.1111/j.1539-6975.2011.01413.x

Iqbal Khan, K. (2012). Effect of Dividends on Stock Prices- A Case of Chemical and Pharmaceutical Industry of Pakistan. Management, 2(5), 20120205. Retrieved from http:/ / article.sapub.org/10.5923.j.mm.20120205.02.html.

Ircham, M., Handayani, S. R., \& Saifi, M. (2014). Pengaruh Struktur Modal dan Profitabilitas terhadap Harga Saham ( Studi pada Perusahaan Makanan dan Minuman yang terdaftar di Bursa Efek Indonesia Tahun 2009-2012 ). Journal of Finance, 11(1), 1-8.

$\mathrm{Ju}$ Chen, $\mathrm{Li}$ and $\mathrm{Yu}$ Chen, S. (2011). The influence of profitability on firm value with capital structure as the mediator and firm size and industry as moderator. Investment Management and Financial Innovations, 8(3).

Keshtavar, Ali; Moeinaddin, Mahmoud; Dehnavi, H. D. 2013. (2013). Need for Capital Management and Capital Structure in the World Today. International Journal of Modern Management Sciences, 2(2), pp:67-74.

Khan, Kanwal Iqbal., Muhamad Amir, Arslan Qayyum, A. N. and M. I. K. (2011). Can Dividend Decisions Affect the Stock Prices: A Case of Dividend Paying Companies of CSE. International Research Journal of Finance and Economics, 76(68), 69-74.

Lestari, D. A. (2019). Pengaruh Keputusan Investasi, Keputusan Pendanaan, Kebijakan Dividen dan Ukuran Perusahaan Terhadap Nilai Perusahaan (Studi Empiris pada Perusahaan Manufaktur Sektor Industri Barang Konsumsi yang Terdaftar di BEI Periode 2015-2017). Universitas Mercu Buana Yogyakarta. https://doi.org/10.20885/jaai.vol17.iss2.art6

Myers S., dan N. M. (1984). Corporate Financing and Investment Decision When Firms have Information Investors do not have. Journal of Financial Economics, 13, p 187-221.

Octaviani, N. K. D., \& Astika, I. B. P. (2016). Profitabilitas Dan Leverage Sebagai Pemoderasi Pengaruh Kebijakan Dividen Pada Nilai Perusahaan. E-Jurnal Akuntansi Universitas Udayana, 3, 2192-2219.

Oktaviani, M., Rosmaniar, A., \& Hadi, S. (2019). Pengaruh Ukuran Perusahaan (Size) Dan Struktur Modal Terhadap Nilai Perusahaan. Balance, XVI(1), 102111.

Pertiwi, D. P. (2018). Pengaruh Profitabilitas Dan Keputusan Investasi Terhadap Nilai Perusahaan Dengan Kebijakan Dividen Sebagai Variabel Mediasi (Studi Pada Perusahaan Food and Beverages yang Terdaftar di Bursa Efek Indonesia Tahun 2013-2017). (Doctoral Dissertation, IAIN SURAKARTA).

Pratama, I. G. G. W., \& Wirawati, N. G. P. (2016). Pengaruh Struktur Modal Dan Profitabilitas Terhadap Nilai Perusahaan Dengan Kepemilikan Manajerial Sebagai Pemoderasi. E- Jurnal Akuntansi Universitas Udayana, 15(3), 17961825.

Puspita, R., \& Hermuningsih, S. (2019). Pengaruh Profitabilitas, Operating Leverage, Terhadap Nilai Perusahaan, Dengan Struktur Modal Sebagai 
Variabel Intervening Pada Perusahaan Food and Beverage yang Terdaftar Di Bursa Efek Indonesia. SEGMEN Jurnal Manajemen Dan Bisnis, 15(1-9).

Putra, I. P. D. P. (2017). Pengaruh Karakteristik Perusahaan dan Kepemilikan Institusional Pada Nilai Perusahaan dengan CSR sebagai Variabel Intervening. E-Jurnal Akuntansi Universitas Udayana, 21(2), 1263-1289.

Ross, S. A., Westerfield, R. W., Jordan, B. D., Lim, J., \& Tan, R. (2016). Fundamental of corporate finance (second). McGraw-Hill Education.

Sabrin, B., Sarita, D., .S, T., \& Sujono4. (2016). The Effect of Profitability on Firm Value in Manufacturing Company at Indonesia Stock Exchange. The International Journal of Engineering And Science (IJES), 5(10), 81-89. https://doi.org/10.1016/0014-4827(80)90264-5

Senata, M. (2016). Pengaruh Kebijakan Dividen Terhadap Nilai Perusahaan Yang Tercatat Pada Indeks LQ-45. Jurnal Wira Ekonomi Mikrosil, 6(01), 73-84.

Sorin, G. A. (2016). The Impact of Dividend Policy On Firm Value. A Panel Data Analysis of Romanian Listed Firms. Journal of Public Administration, Finance and Law THE, 1(10), 107-112. Retrieved from http://www.jopafl.com/uploads/issue10/The_Impact_Of_Dividend_Polic y_On_Firm_Value_A_Panel_Data_Analysis_Of_Romanian_Listed_Firms.pd $\mathrm{f}$

Sugiyarso, G., \& F, W. (2005). Manajemen Keuangan: Pemahaman Laporan Keuangan, Pengelolaan Aktiva, Kewajiban, dan Modal, serta Pengukuran Kinerja Perusahaan. Yogyakarta: Media Pressindo.

Wijaya, B. I., \& Sedana, I. B. . (2015). Pengaruh Profitabilitas Terhadap Nilai Perusahaan (Kebijakan Dividen dan Kesempatan Investasi Sebagai Variabel Mediasi). E-Jurnal Manajemen Unud, 4(12), 4477-4500.

Yanda, A. C. (2018). Pengaruh Struktur Modal, Pertumbuhan Perusahaan, Ukuran Perusahaan dan Profitabilitas Terhadap Nilai Perusahaan pada Perusahaan Manufaktur yang Terdaftar di Bursa Efek Indonesia. Repositori Institusi USU, 1. https:/ / doi.org/10.29264/jakt.v0i0.1924 